\title{
Inefficient Investment and Corporate Sustainable Growth
}

\author{
Jianfeng Zhao ${ }^{1^{*}} \quad$ Liangjin $\mathrm{Li}^{2} \quad$ Xiaoyi Zhang ${ }^{1}$ \\ 1.School of Economics and Management, Shanxi University, $92 \mathrm{Wu}$ Cheng Road, Taiyuan 030006, China \\ 2.The Financial Department, Shanxi University, $92 \mathrm{Wu}$ Cheng Road, Taiyuan 030006, China \\ * E-mail of the corresponding author: zhaojian@sxu.edu.cn
}

\begin{abstract}
The inefficient investment behavior exists widely in enterprises, and few literatures expand its economic consequences to the perspective of sustainable growth of enterprises. This paper selects eligible Chinese A-share private listed companies in Shanghai and Shenzhen exchanges from 2014 to 2018 as the sample to explore whether the inefficient investment has an impact on the firm sustainable growth ability, and whether the inefficient investment under different conditions have different impacts on the sustainable growth ability of enterprises. The empirical results show that the inefficient investment behaviors of private enterprises reduce the sustainable growth ability of enterprises. Whether it is the over-investment or the under-investment, it may inhibit the corporate sustainable growth. The under-investment has more effect on the corporate sustainable growth than the overinvestment. The number of under-investment enterprises is more than over-investment enterprises. According to the different formation mechanisms of under-investment, the under-investment on the condition of sufficient funds has a negative impact on the sustainable growth of the enterprise, which is the performance of ultra-conservation. The under-investment on the condition of insufficient funds has also a significantly negative impact on the corporate sustainable growth to avoid risks. Our evidences are consistent with the hypotheses and have important policy implications.
\end{abstract}

Keywords: Inefficient investment, Over-investment, Under-investment, Corporate sustainable growth DOI: $10.7176 / \mathrm{EJBM} / 13-24-02$

Publication date: December $31^{\text {st }} 2021$

\section{Introduction}

Despite its poor legal and financial systems, China has one of the fastest growing economies in the world, and represents a significant counter example to the findings of the existing literature (most of which exclude China) on law, institutions, finance and growth (Allen et al. 2005). Several interesting findings, of special relevance to this paper, emerge from the analyses in Allen et al. First, the Private Sector in China dominates the State (that is state-owned companies) and the Listed (that is publicly traded companies) sectors in terms of both the size of output and the growth trend. Second, the success of a firm in the Private Sector depends critically on the support from local government.

In the past 40 years of Chinese reform and opening up, corporations have achieved rapid growth. In the next 40 years, corporate sustainable growth in China is a more core task. Firm growth is a difficult problem for corporations. A large number of failed cases tell us that many corporations pursue the high growth in sales and speedy enterprise expansion, in line with the Chinese proverb about pulling up the seedlings to help them grow, and the revenue and profits from such growth are often not sustainable in the long term. In fact, there are almost as many bankrupt corporations due to excessive pursuit of growth rate as those due to lack of development

(Chen,W. 2008) . Therefore, it is necessary for corporations to reexamine their growth from the perspective of long-term sustainability.

The basic activity of a corporation is resource allocation. The process of sustainable development and growth of corporations is to absorb and allocate resources continuously. Through their own financing and investment strategies, within the limited resources owned by corporations, corporations can reasonably allocate resources and obtain the best benefits. The profit level, production capacity and growth capacity of a corporation all depend on its investment level and effective utilization of resources. Financing brings rich cash flow to the corporation, and provides the basic material guarantee for the sustainable operation of the corporation. Investment provides the power and opportunity for the survival and development of the corporation. However, managers can not accurately predict the rate of return on each investment project, and no every investment decision can bring positive cash flow to the corporation. Therefore, the academia divides the investment behavior into the efficient investment and the inefficient investment. The efficient investment can increase the firm value, while the inefficient investment reduces the firm value (Du et al. 2011; Zhan \& Wang 2013). Will the inefficient investment behavior affect the long-term sustainable growth ability of corporations?

Nowadays, private economy, collective economy and state-owned economy have formed the pattern of "three parts of the world" in China, among which the development pressure of private economy is the biggest. Therefore, how to promote the development of private economy to solve the plight of private enterprises has always been the focus of scholars. Because state-owned enterprises bear part of the social responsibility of public affairs, the 
investment objectives of state-owned enterprises is not only about efficiency. Compared with state-owned enterprises, private enterprises are relatively less constrained and their investing behavior is more rational. Based on these, this paper takes Chinese private listed companies as the research object, extends the economic consequences of investment efficiency to the perspective of sustainable growth of enterprises, and makes an empirical analysis of the relationship between inefficient investment and corporate sustainable growth. The data in this study is comprised by the annual data of 1083 private listed companies on the Shanghai and Shenzhen Main Board Market which covers the period from 2014 to 2018.

The main contributions of this paper are as follows: first, it is helpful to study the investment efficiency in heterogeneous enterprises, and analyze the different effects of corporate inefficient investment on sustainable growth transmission from the theoretical models and empirical analyses. Second, according to different formation mechanism, the relationship between the under-investment on different formation conditions and the sustainable growth rate is further studied. It is helpful to understand the influence of under-investment differentiation on corporate sustainable growth. In addition, the results can be applied to national decision makers to improve the quality of state-owned enterprises governance and reformation, and to enterprises to find the optimal investment strategy and promote the sustainable growth ability of enterprises in developing countries.

The remainder of this study is structured as follows. First, an overview of the existing literature on the impact of inefficient investment on corporate sustainable growth and the roles of firms' characters for the impact are presented. On that basis, the main hypotheses are developed. Next, the data and the variables are described and empirical models are formulated. The results are then presented and key findings are discussed. Finally, the key findings of the study are summarized and the implications for policy and business practice are drawn.

\section{Literature Review}

\subsection{Investment efficiency}

Based on the theory of optimal capital structure, Modigliani and Miller (1958) point out the reference standard of company investment that only the positive NPV investment projects can be selected, and the company should invest all positive NPV projects. However, the interests of the company's decision-makers and the company's owners are inconsistent in the actual investment activities, due to the information asymmetry and agency problems (Stein 2001), resulting that the managers of the company actually base on their own interests to make investment behavior. The investment behavior is not conducive to the maximization of corporate value (Liu 2016; Huang 2017). The investment efficiency of the company is not enough. A large number of studies have shown that corporate investment behavior affects corporate value. According to the cost model of equity and debt financing, the existence of moral hazard makes managers in enterprises over-invest based on management power, and the adverse selection in capital market may lead to the under-investment. When the enterprise under-invests, it indicates that the enterprise has abandoned the project with NPV $>0$; when the enterprise invests excessively, it indicates that the enterprise has invested in the project with NPV $<0$ (Jensen 1986). The under-investment and the over-investment are both the inefficient investment obviously, which can damage the value of the company.

From the perspective of financing constraints, external investors and creditors cannot obtain the complete information of the enterprise for the information asymmetry, so the enterprise uses the ways of increasing the risk premium to avoid risks, and then the financing costs for adopting different financing methods are different. When the enterprise needs to raise funds from the outside but is restricted, the investment decision of the enterprise would be affected, resulting in the inefficient investment. Myers and Majluf (1984) report that information asymmetry usually increases the external financing costs of enterprises, leading to managers abandoning some projects which the net present values are greater than zero, resulting in the insufficient investment. Zhang et al. (2017) show that financing constraints can lead to the inefficient investment behavior.

With the separation of ownership and management rights in modern companies, there is the principal-agent relationship. Lerman and Means (1932) point out that the inefficient investment would occur in the investment decisions of enterprises because the interests and purposes of managers are different from those of owners. Jensen (1976) points out that the results of the manager's hard-working operation are shared by the shareholders, while the risks are borne by the manager, which would inevitably lead to the manager's decision-making differing from the goal of shareholders' value maximization, and tending to maximize the manager's own interests. In a word, the contradiction between shareholders and managers can inevitably lead to the inefficient investment behavior in the separation of ownership and management rights. Hart (1995) points out that the management has a strong desire to establish his own business empire in order to obtain private benefits of the personal reputation, power, status and remuneration, which leads to the over-investment.

In addition to the above factors, the scholars also find the other influencing factors of investment efficiency from the perspective of behavioral finance. Roll (1986) is one of the first scholars to study the direction of managerial overconfidence, pointing out that the managerial overconfidence would overestimate the earnings in merger and acquisition activities, leading to over-investment. Xie \& Kong (2018) combine the behavioral finance theory with the traditional finance theory, proving that the managerial overconfidence has a negative effect on 
investment efficiency. Zhao (2020) find that the regional differences and the entrepreneurs' risk-taking propensity all impact on investment behavior. Wang et al. (2016) prove that the external unfairness of compensation can lead to the jealousy of the management based on the social comparison theory, so the managers would seek the alternative compensation and then lead to the inefficient investment.

\subsection{Corporate sustainable growth}

The concept of corporate sustainable development originated from the western scholars in the 1970s. Robert C. Higgins (1981) proposed the concept of sustainable growth value creation. The creation of sustainable value of enterprises takes financial relations as a bridge, and needs to maintain a sustainable relationship with stakeholders. The sustainable growth value creation is the basic asset and the ultimate source of corporate wealth. In many theories, Higgins model and Van Horn model based on accounting standards are the most accepted, widely spread and influential quantitative methods about sustainable growth rate, and form a relatively mature theoretical system.

After the concept of financial sustainable development was introduced into China, Chinese scholars also made a lot of practical exploration and theoretical construction, and got many theoretical results in line with the actual situation. Tang (2005) compares the sustainable growth model based on cash flow with the sustainable growth model based on accounting, and find that the sustainable growth model based on cash flow is more realistic. Han (2015) compares the sensitivity of each financial ratio in the sustainable growth model based on accounting, and believes that the improvement of asset turnover rate and equity multiplier plays more significant roles in the sustainable growth rate of enterprises.

The essential activity of an enterprise lies in the allocation of resources, which determines its sustainable growth ability (Yang et al. 2011). The sustainable growth is the expansion of the field of corporate growth. Scholars generally believe that the ability of corporate sustainable growth is a result of the interaction of many aspects. Yan (2016) summarizes the relevant literature and concludes that the factors affecting sustainable growth mainly include corporate cycle, capital cost, manager quality, technology innovation, etc. However, the impact of investment behavior on sustainable growth is ignored. At the same time, the research on investment efficiency is mainly focused on influencing factors of investment efficiency, and the research on the economic consequences of investment efficiency is only limited to corporate value, business performance and stock price stability. Few literatures expand the economic consequences of investment efficiency to the perspective of corporate sustainable growth. Therefore, Yan proposes that the economic consequences of investment efficiency can be extended to the sustainable growth of enterprises in the future. By 2019, Yang et al. (2011) find that the under-investment behavior of small and medium-sized technology-based enterprises on the Growth Enterprise Market would inhibit the sustainable growth ability of enterprises. Specifically, this inhibition is mainly caused by the lack of operational investment without a cash flow gap, while the relationship between the lack of investment with a cash flow gap and the sustainable growth rate is not significant. Based on this, this paper extends the research scope of the relationship between inefficient investment and sustainable growth ability of enterprises to private enterprises.

\section{Theoretical Analysis and Research Hypothesis}

\subsection{Inefficient investment and corporate sustainable growth}

At present, the open technology and market environment make different industries challenge each other. How to survive in this highly uncertain situation has always been a research topic. Once an enterprise encounters great environmental changes, those hidden operational defects may be exposed, and the sustainable growth ability of an enterprise can really prove its adaptability to the market (Chen,C. 2018). Sustainable growth is the optimal growth state that an enterprise can achieve.

The investment behavior has become an essential part of corporate extended reproduction. A correct investment decision may bring a leap development opportunity for the enterprise; on the contrary, a wrong investment decision may also make the enterprise face decline. Due to the defects of capital market, the influence of real environment and human factors makes the internal and external environment of enterprises uncertain

(Zhu,X.; Li,A.; Tang,Y. 2016). The enterprise can't be absolutely sure that the investment decision is correct, and the result prediction of the project can't be absolutely accurate, so it can't be sure that each investment can bring positive cash flow to the enterprise. With the influence of information asymmetry, financing constraints, agency conflicts and other factors, inefficient investment may appear in enterprises

Generally speaking, the under-investment is to give up the positive-NPV projects, while the over-investment is to invest projects whether the project's NPV is positive or not. Obviously, the over-investment and the underinvestment are not conducive to the maximization of firm value. In the long run, it would inevitably have a negative impact on the long-term development of enterprises. In such fierce market competition, good investment opportunities mean the improvement of core competitiveness. If an enterprise wants to maintain the sustainable growth, it needs to have leading market core competitiveness, strong profitability, a solid financial foundation and corporate comprehensive ability on the basis of its core business. It can be inferred that the investment efficiency has an inseparable relationship with the sustainable growth of enterprises. Therefore, this paper puts forward the 
hypotheses:

- Hypothesis 1a: The inefficient investment inhibits the corporate sustainable growth.

- Hypothesis $1 \mathrm{~b}$ : The over-investment inhibits the corporate sustainable growth.

- Hypothesis 1c: The under-investment inhibits the corporate sustainable growth.

\subsection{Under-investment under different conditions and corporate sustainable growth}

As described in the previous literature, the over-investment behavior in inefficient investment is basically caused by conflicting goals of managers and shareholders and the opportunism of managers. Jensen (1986) believes that when a company has more free cash flow, the manager of the company may ignore the interests of shareholders, and generate the idea of investing this part of free cash flow in new projects that can make the company expand, so as to meet his own various desires of money or non-money, or to gain a sense of accomplishment from the expansion of the company. These lead to the over-investment.

Existing studies generally believe that the under-investment is affected by financing constraints. (Richardson 2006) Financing constraints can be understood as the lack of financing channels for enterprises to raise enough funds at reasonable cost. However, even if the enterprise itself has sufficient cash flow, it may also make the investment decision of under-investment. Fang et al. (2013) believe that there are different formation mechanisms of the inefficient investment (Fang,H.; Jin,Y. 2013), and the cash flow level of internal operating activities is an important determinant of the corporate investment decision (Fazzari,S.M.; Hubbard,R.G. 1988).

There are two reasons for the under-investment. One is that the enterprise cannot get financing for financing constraints from the information asymmetry between the borrower and the lender when it is short of funds, so the enterprise gives up the investment project with higher income. The other is that the manager or shareholders give up the investment according to the feasibility analysis of the project when the enterprise has sufficient funds. In fact, enterprises need not to invest all projects whose net present values are greater than zero. It may also be a rational performance to give up some investment projects when the enterprise is short of funds; however, the insufficient investment when the funds are sufficient may be an ultra-conservation performance which may cause the enterprise to lose some good investment opportunities. Therefore, compared with the over-investment behavior, the research on the under-investment cannot be generalized. This paper puts forward the hypotheses:

- Hypothesis 2a: The under-investment on the condition of insufficient funds has a significantly negative effect on the corporate sustainable growth.

- Hypothesis 2b: The under-investment on the condition of sufficient funds has a significantly negative effect on the corporate sustainable growth.

\section{Research Design}

4.1 Data

Our sample period is from 2014 to 2018 . Benefit of restricting our sample to this period is that the reported financial information of China's private listed firms is consistent over this period of time. We select 1083 private listed companies on the Shanghai and Shenzhen Main Board Market. Our financial variables and stock return data used in this paper are derived from the CSMAR database. Other variables data are derived from the WIND database. Financial firms are excluded in line with prior studies. Our final sample consists of 4254 firm-year observations in China from 2014 to 2018.

\subsection{Variable Selection and Quantification}

- $\quad$ Sustainable growth rate $(S G R)$

Theoretically speaking, there are two models to measure the sustainable growth, one is based on the accounting dimension, and the other is based on the cash flow dimension. For avoiding the large fluctuation between the calculation results and the actual sustainable growth capacity, scholars often use the model based on accounting caliber to measure the sustainable growth rate. In the two models with the highest acceptance and widest spread from the accounting view, Higgins (2003) selects the opening data of Owners' Equity, and Van Horne (2000) selects the closing data, but the opening data can more accurately measure the sustainable growth rate of the enterprise in that year. And Higgins Model clearly answers the factors that affect the financial sustainable growth ability of enterprises, which is easier to understand. So, this paper uses Higgins' Model to calculate the sustainable growth rate (SGR):

$$
S G R=P \times A \times T \times R /(1-P \times A \times T \times R)
$$

where $P$ measures Net Profit Ratio, calculated as net profit divided by sales. $A$ measures Assets Turnover, calculated as sales divided by total assets at the end of the period. $T$ measures Equity Multiplier, calculated by total assets at the end of the period divided by total owners' equity at the beginning of the period. $R$ measures Retained Earnings Ratio, calculated as 1 plus Dividend Paid Ratio. 
- Investment efficiency (Invest)

There are three models to measure the investment efficiency of enterprises. FHP (1988) proposes the investmentcash flow sensitivity model to analyze the sensitivity of investment spending to internal cash flow from the perspective of financing constraints. Vogt (1994) develops the investment efficiency evaluation model on the basis of FHP's model. Richardson (2006) model solves the defect that the former two models can only judge whether the investment of an enterprise belongs to the inefficient investment, but the degree of inefficient investment is not specific. This model can measure the degree of inefficient investment with specific values. The fitting value of the model is the investment level of enterprises to maintain normal operation, and the residual value is the degree of difference. One part is the investment level calculated by the explanatory variables to maintain the normal operation of the enterprise; the other part is the inefficient investment greater than or less than the investment level of the normal operation.

Referring to the optimal investment model of Richardson (2006) and Wu et al. (2012), this paper establishes the estimation model of expected normal additional investment rate of the company:

$$
\begin{aligned}
\text { Invest }_{i, t}= & \beta_{0}+\beta_{1} Q_{i, t-1}+\beta_{2} C F_{i, t-1}+\beta_{3} \text { Age }_{i, t-1}+\beta_{4} L E V_{i, t-1} \\
& +\beta_{5} \text { Size }_{i, t-1}+\beta_{6} R O E_{i, t-1}+\beta_{7} \text { Invest }_{i, t-1}+\text { Industry \&Year-fixed effects }+\varepsilon_{i, t}
\end{aligned}
$$

where Invest $t_{i, t}$ measures corporate investment for a given company in a given year, calculated with the difference between the expenditure for the acquisition and construction of fixed assets, intangible assets and other long-term assets and the income from the disposal of fixed assets, intangible assets and other long-term assets ,divided by total assets. $Q_{i, t-l}$ (for Tobin's Q ratio) measures market valuation for a given company in a given last year, calculated as total market value of equity plus total debt, where the market value of equity is the market value of tradable shares plus the book value of non-tradable shares, divided by the book value of total assets (Lin and $\mathrm{Su}, 2008) . C F_{i, t-l}$ is the net cash flow from operating activities for a given company in a given last year divided by total assets at the end of the year. $A g e_{i, t-l}$ is the number of years since listing for a given company in a given last year. $L E V_{i, t-l}$ is the total debt divided by total assets at the end of the year for a given company in a given last year. Size $\mathrm{i}_{\mathrm{i}-1}$ is natural logarithm of the book value of total assets at the end of the year for a given company in a given last year. $R O E_{i, t-1}$ (for Return on equity rate) for a given company in a given last year, is earnings before interest and tax divided by owners' equity at the end of the year. Invest $t_{i, t-1}$ measures corporate investment for a given company in a given last year. Year and industry fixed effects are included. Standard errors are clustered at the firm level to account for within-firm serial correlation (Petersen, 2009).

- Inefficient investment $(I N V)$

By model(2), the residual term $\varepsilon_{i, t}$ of the regression equation shows the inefficient investment (INV), whose

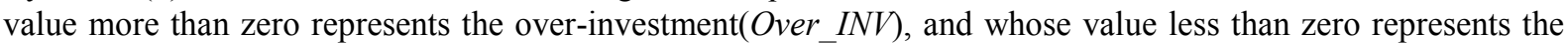
under-investment(Under_INV). In this paper, the absolute value of $\varepsilon_{\mathrm{i}, \mathrm{t}}$ is used to express the level of inefficient investment(INV) for a given company in a given year. The greater $I N V$ is, the more serious the level of inefficient investment is.

As for the division of under-investment under different formation mechanisms, referring to the internal cash flow gap used in the study of Chen et al. (2015) and Xiao (2010), this paper further divides the sample with underinvestment into two groups, the under-investment with cash flow gap and the under-investment without cash flow gap, respectively corresponding to the under-investment on the condition of insufficient funds, and the underinvestment on the condition of sufficient funds.

The internal cash gap is calculated as expected normal additional investment rate plus the internal cash holdings in the current year, where the internal cash holdings include the accrued accumulated depreciation plus the accrued accumulated amortization, less net cash flow from operating activities, then divided by total assets at the beginning of the year. Expected normal additional investment rate is measured by net increase in fixed assets, intangible assets and other long-term assets divided by total assets at the beginning of the year.

The formula divides the under-investment sample. When the value of internal cash gap is positive, it indicates that the company needs to refinance, and these companies are divided into the sample of under-investment on the condition of insufficient funds (Under $I N V_{l}$ ); otherwise, when the value is equal to zero or negative, it indicates that the company has sufficient funds, and those companies are divided into the sample of under-investment on the condition of sufficient funds (Under_INV 2$)$ 。

\subsection{Regression Model}

Referring to the literature of Jensen (1976) and Zhang et al. (2015), we use Tobit's model and estimate the following regression to test the inhibition effect of inefficient investment on sustainable growth capacity:

$$
\begin{aligned}
S G R_{i, t}= & \beta_{0}+\beta_{1} I N V_{i, t}+\beta_{2} \text { Size }_{i, t}+\beta_{3} C R R_{i, t}+\beta_{4} S H A R E_{i, t} \\
& +\beta_{5} I N N_{i, t}+\text { Industry \&Year-fixed effects }+\varepsilon_{i, t}
\end{aligned}
$$

where $S G R_{i, t}$ is Sustainable growth rate as the dependent variable, $I N V_{i, t}$ is Inefficient investment as the independent 
variable for a given company in a given year. In order to test the above hypotheses, this paper introduces control variables: $S I Z E_{i, t}, S H A R E_{i, t}, C R R_{i, t}, I N N_{i, t}$ described in Table1, and Year and industry fixed effects are included.

Table1. Definition and quantization of variables

\begin{tabular}{|l|l|l|l|}
\hline Types & Variable & Symbol & Variable definition and quantization \\
\hline $\begin{array}{l}\text { Dependent } \\
\text { variable }\end{array}$ & $\begin{array}{l}\text { Sustainable growth } \\
\text { rate }\end{array}$ & $S G R$ & Obtained by model(1) \\
\hline \multirow{4}{*}{$\begin{array}{l}\text { Independent } \\
\text { variable }\end{array}$} & $\begin{array}{l}\text { Inefficient } \\
\text { investment }\end{array}$ & $I N V$ & Absolute value of residual obtained by model $(2),\left|\varepsilon_{\mathrm{i}, \mathrm{t}}\right|$ \\
\cline { 2 - 4 } & Over-investment & Over_INV & $\varepsilon_{\mathrm{i}, \mathrm{t}}$ more than 0 \\
\cline { 2 - 4 } Control variable & Under-investment & Under INV & $\mid \varepsilon_{\mathrm{i}, \mathrm{t}}, \varepsilon_{\mathrm{i}, \mathrm{t}}$ less than or equal to 0 \\
\hline & Size & Size & Natural logarithm of total assets at the end of the year \\
\cline { 2 - 4 } & $\begin{array}{l}\text { Share } \\
\text { Concentration }\end{array}$ & SHARE & Shareholding ratio of top ten shareholders \\
\cline { 2 - 4 } & $\begin{array}{l}\text { Expense rate } \\
\text { during sales }\end{array}$ & CRR & $\begin{array}{l}\text { Ratio of the sum of selling expenses, management } \\
\text { expenses and financial expenses to operating revenue }\end{array}$ \\
\cline { 2 - 4 } & Innovative ability & $I N N$ & Ratio of R\&D investment to operating revenue \\
\hline
\end{tabular}

\section{Empirical results and analysis}

\subsection{Descriptive Statistics}

Table2. Descriptive statistics of main variables

\begin{tabular}{|l|l|l|l|l|l|l|}
\hline & SGR & INV & SHARE & CRR & INN & Size \\
\hline Mean & 0.0432 & 0.0540 & 53.1273 & 0.2152 & 0.0730 & 22.0140 \\
\hline Std dev & 0.1587 & 0.0826 & 14.1353 & 0.4117 & 0.1083 & 1.0188 \\
\hline Median & 0.0350 & 0.0327 & 53.2937 & 0.1861 & 0.0423 & 21.9708 \\
\hline Min & -0.3432 & 0 & 12.7074 & 0.1121 & 0 & 16.7872 \\
\hline Max & 0.1574 & 0.9853 & 82.4231 & 0.4161 & 1.5885 & 29.3899 \\
\hline N & 4254 & 4254 & 4254 & 4254 & 4254 & 4254 \\
\hline
\end{tabular}

Table 2 presents a summary of the descriptive statistics for our sample of companies. There is a wide dispersion of sustainable growth rate across enterprises. The sustainable growth rates of some enterprises are negative for problems in financial policies and operating efficiency, and negative values are assigned zero in subsequent regression. At the same time, a few enterprises have higher and more prominent sustainable growth rates, which make the median less than the mean value. The differences in inefficient investment are also quite different. Some enterprises show the high degree of inefficient investment, which makes the median less than the mean value.

\subsection{Correlation Analysis}

Before constructing a formal, multivariate regression model, we checked for the potential threat of multicollinearity between some of the previously identified explanatory and control variables by calculating the Pearson Correlation Coefficients between them in Table 3. This study illustrates the phenomena found in this table. The correlation coefficient between inefficient investment and sustainable growth rate is significantly negative, which confirms that most sustainable companies are characterized by lower inefficient investment. Correlation coefficients between other variables are relatively small, so a very low general threat of multicollinearity is noted.

Table 3. Pearson's correlation coefficient test for pair-wise variables

\begin{tabular}{|l|l|l|l|l|l|l|}
\hline & SGR & INV & SHARE & CRR & INN & Size \\
\hline SGR & 1 & & & & & \\
\hline INV & $-0.040^{* *}$ & 1 & & & & \\
\hline SHARE & $0.080^{* * *}$ & $0.131^{* *}$ & 1 & & & \\
\hline CRR & -0.009 & -0.006 & -0.008 & 1 & & \\
\hline INN & $-0.003 *$ & $0.034^{*}$ & $-0.031^{*}$ & -0.013 & 1 & \\
\hline Size & $0.109 * * *$ & 0.029 & $0.167 * *$ & $0.034 *$ & 0.010 & 1 \\
\hline
\end{tabular}

Note: $* * *, * * *$ are significant at the levels of $1 \%, 5 \%$, and $10 \%$ (two-tailed), respectively.

\subsection{Regression Analysis}

The results are presented in Table4 to visually compare the regression results of different sample. The results of Equation (3) parameter estimation for the full sample of firms offer additional support for the view that there is a negative relationship between inefficient investment and corporate sustainable growth in Column (1), which is consistent with our main hypothesis. F-statistic is significant at 5\% level, and the equation is effective as a whole. 
Table 4. Regression results (Higgins' model)

\begin{tabular}{|l|l|l|l|l|l|}
\hline & Full sample & Over_INV & Under_INV & Under_INV $I_{1}$ & Under_INV $_{2}$ \\
\hline \multirow{2}{*}{ INV } & $-0.052^{* * *}$ & $-0.070^{* * *}$ & $-0.086^{* * *}$ & $-0.143^{* * *}$ & $-0.061^{* *}$ \\
& $(-3.361)$ & $(-2.696)$ & $(-4.514)$ & $(-4.641)$ & $(-2.547)$ \\
\hline \multirow{2}{*}{ CRR } & -0.011 & $-0.044 * *$ & -0.004 & -0.004 & -0.003 \\
& $(-0.700)$ & $(-1.715)$ & $(-0.230)$ & $(-0.131)$ & $(-0.141)$ \\
\hline \multirow{2}{*}{ SHARE } & $0.070^{* * *}$ & $0.052^{* *}$ & $0.080^{* * *}$ & $0.093 * * *$ & $0.067 * * *$ \\
& $(4.485)$ & $(1.973)$ & $(4.164)$ & $(2.958)$ & $(2.770)$ \\
\hline \multirow{2}{*}{ INN } & -0.013 & -0.019 & -0.012 & 0.029 & -0.019 \\
& $(-0.874)$ & $(-0.734)$ & $(-0.635)$ & $(0.941)$ & $(-0.814)$ \\
\hline \multirow{2}{*}{ Size } & $0.100^{* * *}$ & $0.120^{* * *}$ & $0.083 * * *$ & $0.189 * * *$ & $0.044 *$ \\
& $(6.481)$ & $(4.647)$ & $(4.295)$ & $(5.597)$ & $(1.841)$ \\
\hline $\mathrm{R}{ }^{2}$ & 0.018 & 0.020 & 0.021 & 0.073 & 0.008 \\
\hline F-statistic & $16.233^{* *}$ & $7.229 * *$ & $13.089 * *$ & 16.441 & 3.835 \\
\hline $\mathrm{N}$ & 4342 & 865 & 3477 & 1364 & 2113 \\
\hline
\end{tabular}

Note: $* * *, * * *$ are significant at the levels of $1 \%, 5 \%$, and $10 \%$, respectively.

Next, we repeat the Equation (3) parameter estimation for over-investment firms and under-investment firms separately in Column (2)-(3). The over-investment and the under-investment have negative impact on corporate sustainable growth respectively, and the values are significant at the $1 \%$ level. The impact of under-investment is more than the over-investment. Hypotheses 1 are proved. Combined with the practice, the investment is an important part of the reproduction and large-scale development for an enterprise. For a private enterprise, the under-investment easily causes the enterprise to lose certain investment opportunities and affects the long-term development of the enterprise. The more valuable investment opportunities are given up, the more negative impact on corporate sustainable growth ability in the long run is. In the same way, if an enterprise invests excessively, too much cash would flow to projects with negative NPV, which is also unfavorable to the long-term sustainable development of the enterprise. The more inefficient investment is, the more obvious the inhibition on corporate sustainable growth ability is.

About control variables in Column (1)-(3), the correlation coefficients between Size and SGR are 0.100, 0.120 and 0.083 , and they are all significant at $1 \%$ level. SHARE has also positive impact on SGR at $1 \%$ or $5 \%$ level. The results show that the increase of firm size and equity concentration are conducive to resist risks and promote the corporate sustainable growth. In Chinese private listed companies, the equity concentration helps corporate sustainability.

Finally, we repeat the Equation (3) parameter estimation for the under-investment on the condition of insufficient funds and sufficient funds in Column (4) - (5).

In Column (4) of Under_INV , for the sample of under-investment on the condition of insufficient funds, there is a significantly negative correlation between inefficient investment and corporate sustainable growth rate at $1 \%$ level, so the hypothesis 2 a holds. In fact, not all projects with positive NPV need to be invested. When the enterprise is short of funds, it may also be a rational manifestation of avoiding risks to give up some investment projects properly. But the behavior of insufficient investment can hurt firm value. In the long run, too many valuable investment projects are given up, which can weaken the development power equivalently and cannot help long-term development of the enterprise. With the support of the government and banks for private enterprises, the financing channels become more and the financing cost is reduced. Therefore, private enterprises should actively understand relevant policies for solving their own financial problems, and then they have sufficient funds to maintain sustainable growth. For the results of control variables, Size and SHARE are positively correlated with SGR at $1 \%$ level. The correlation between other control variables and sustainable growth rate is not significant.

In Column (5) of Under_INV 2 , for the sample of under-investment on the condition of sufficient funds, there is a significantly negative correlation between inefficient investment and sustainable growth rate at $5 \%$ level, which supports the hypothesis $2 \mathrm{~b}$. The under-investment on the condition of sufficient funds has a significantly negative impact on the long-term sustainable growth. The reason for under-investment on the condition of sufficient funds may be that managers misjudged and gave up the investment projects with high returns. In addition, the number of high-quality investment projects is reducing in the whole society, which causes enterprises to have sufficient funds but no project to invest. In the long run, this situation is extremely unfavorable for the development of enterprises, and results in significantly negative correlation between under-investment on the condition of sufficient funds and sustainable growth rate. It is also possible that there are misstatements in financial statements of enterprises, and the sufficient funds shown in the statements are not in line with the actual situation; or firms' funds are used for on-the-job consumption, so that enterprises have no funds for investing. Furthermore, the professional level of managers, incentive policies for managers and their own interests may make enterprises give up some projects with high returns. About control variables, Size and SHARE are positively correlated with SGR 
at $1 \%$ level.

\subsection{Further Robustness Checks}

Table5. Regression results (Van Horn's model)

\begin{tabular}{|l|l|l|l|l|l|}
\hline & Full sample & Over_INV & Under_INV & Under_INV 1 & Under_INV $_{2}$ \\
\hline INV & $-0.082 * * *$ & $-0.094 * * *$ & $-0.144 * * *$ & $-0.154 * * *$ & $-0.136^{* * *}$ \\
& $(-5.383)$ & $(-3.657)$ & $(-7.766)$ & $(-4.983)$ & $(-5.813)$ \\
\hline CRR & $-0.042 * * *$ & -0.183 & -0.006 & -0.004 & -0.004 \\
& $(-2.791)$ & $(-7.167)$ & $(-0.310)$ & $(-0.143)$ & $(-0.185)$ \\
\hline SHARE & $0.101 * * *$ & $0.076 * * *$ & $0.115 * * *$ & $0.105 * * *$ & $0.109 * * *$ \\
& $(6.556)$ & $(2.953)$ & $(6.068)$ & $(3.333)$ & $(4.588)$ \\
\hline INN & -0.001 & -0.004 & -0.018 & 0.018 & 0.002 \\
& $(-0.088)$ & $(-0.170)$ & $(-0.970)$ & $(0.592)$ & $(0.093)$ \\
\hline SIZE & $0.147 * * *$ & $0.084 * * *$ & $0.147 * * *$ & $0.174 * * *$ & $0.136 * * *$ \\
& $(9.616)$ & $(3.307)$ & $(7.800)$ & $(5.492)$ & $(5.746)$ \\
\hline$R^{2}$ & 0.041 & 0.049 & 0.061 & 0.073 & 0.050 \\
\hline F-statistic & 37.020 & 16.556 & 37.114 & 16.405 & 19.515 \\
\hline N & 4342 & 865 & 3477 & 1364 & 2113 \\
\hline
\end{tabular}

Note: $* * *, * *, *$ are significant at the levels of $1 \%, 5 \%$, and $10 \%$, respectively.

It is comforting to have obtained consistent findings from these different tests, which all lend support to the ineffective investment in the transitional Chinese economy hurts, rather than helps, firms. Taken together, the results are consistent with the prediction.

In order to make the results more robust and prove the hypotheses, this paper adopts Van Horn's model to recalculate the sustainable growth rate into the regression model. We repeat the Equation (3) parameter estimation shown in Table 5. On the regression results, although the measurement model of the sustainable growth rate has been changed, the results are basically consistent with the prediction of the previously selected Higgins' model. There is a significantly negative correlation between the inefficient investment and the sustainable growth rate of enterprises at $1 \%$ level. The hypotheses of this paper are verified by robustness test.

\section{Conclusions and Discussions}

\subsection{Conclusions and Implications}

In recent years, Chinese government has continuously issued relevant policies to support the development of private enterprises, and constantly broaden the financing channels of private enterprises. In a certain extent, the development of private enterprises has been recognized. However, the inefficient investment caused by the macro environment or managers is not good for the long-term development of enterprises. In the long run, it can seriously affect the sustainable development of enterprises.

Based on the sample of A-share private listed companies in Shanghai and Shenzhen Stock Exchange in China from 2014 to 2018, this paper explores the relationship between the inefficient investment and sustainable growth capacity with reference to Tobit's model, and further investigates the two kinds of inefficient investment. The conclusion is as follows: the inefficient investment, whether the over-investment or under-investment behavior of private enterprises, has a negative impact on the long-term sustainable growth of enterprises. The inhibition effect of under-investment on the sustainable growth of enterprises is significant no matter what situation causes the under-investment. On the traits of firms, firm size and share concentration have positive impact on the corporate sustainable growth.

The conclusions of this study have the following policy implications:

First, private enterprises should actively solve the under-investment on the condition of insufficient funds to maintain the sustainable growth. Enterprises should start from their own, explore in depth national fiscal and tax policies, introduce new financing methods such as venture capital, intellectual property pledge, or establish partnership with large enterprises or similar small and medium-sized enterprises to enhance the financing capacity. The management should also re-establish investment policies, credit policies and collection policies, so as to make full use of the internal working capital of enterprises.

Second, local governments should optimize the macro investment environment for the under-investment on the condition of sufficient funds. The management should also improve their professional quality, establish the sound project evaluation system and internal management system, and formulate a reasonable expected rate of return, so that the decision-makers have rules to follow. Enterprises should also make full use of internal liquidity to avoid blind investment, and prevent the cash flow from being used for on-the-job consumption.

Finally, enterprises should give managers relevant compensation and equity incentive mechanism to reward their decision-making which increases the value of the enterprise, and make up for the corresponding risks that they 
undertake, so that the interests and objectives of managers are close to those of shareholders to solve the overinvestment. They should use scientific methods to make more rational decisions and improve investment efficiency.

\subsection{Limitations and Future Research Directions}

Although our study offers several new insights to the inefficient investment and corporate sustainability literature, it is not without limitations.

Our empirical evidence, in conjunction with a large Chinese and English literature as well as anecdotal evidence, only examines the relations between the inefficient investment and corporate sustainable growth in the context of China's transitional economy. A country's political system affects corporate finance and governance outcomes (Alzahrani, M. 2012; An,Z. 2012), so the fact could have changed corporate investing behavior, which could have affected our findings. In order to address these shortcomings, future research designs could investigate the influential role of the inefficient investment on corporate sustainable growth from other countries. All in all, future research lines are still plentiful.

Moreover, we did not differentiate among enterprises that belong to traditional industry or high technology industry, and not distinguish enterprises with different duration time, but these factors may play an important role in corporate investment or sustainable growth. Thus, future studies should replicate our analysis with a focus on differences among enterprises.

Finally, further empirical research is needed to understand additional moderating effects in the relationship between inefficient investment and corporate sustainable growth (e.g., regional characters, management attitudes, and corporate culture), especially there seems to be a relation between managers' values and corporate investment, which can significantly affect the decision-making process in enterprises.

\section{References}

Chen,W. (2008), "Research on Firm's Sustainable Growth Management", Chinese Financial \& Economic Publishing House: Beijing, China.

Du,X.; Zeng,Q. \& Du,Y. (2011), "Political connections, over-investment and corporate value: based on stateowned public listed companies", Journal of Financial Research 8,93-109.

Zhan,L. \& Wang,Y. (2013), "Management incentive, over-investment and corporate value", Nankai Business Review 3,36-46.

Modigliani,F. \& Miller,M.H. (1958), "The cost of capital, corporation finance and the theory of investment", American Economic Review 3,261-297.

Stein,J.; George,C.; Stulz,R., et al. (2001), "Agency, information and corporate investment”, Social Science Electronic Publishing: Beijing, China,

Liu,S.; Ma,C. (2016), "Manager's heterogeneity and its effect on restricting the tunneling behavior of large shareholder", Economic Research Journal 4,129-145.

Huang,Q.(2017),"Management power, institutional investor heterogeneity and capital allocation efficiency" .Modern Finance \& Economics Journal of Tianjin University of Finance and Economics 7,78-89.

Jensen, M. (1986), “Agency Costs of Free Cash Flow, Corporate Finance, and Takeovers”, American Economic Review 2,323-329.

Myers,S.C.; Majluf,N.S.( 1984), "Corporate financing and investment decisions when firms have information that investors do not have", Journal of Financial Economics 13,187-221.

Zhang,Y.;Zhang,F.;Li,Y. (2017), "Accounting conservatism, financing constraints and investment efficiency”, Accounting Research 9,35-40.

Lerman,J.; Means,J.H.(1932), “Cardiovascular symptomatology in exophthalmic goiter”, American Heart Journal 10,55-65.

Jensen,M.; Meckling,W.(1976) "Theory of the Firm: Managerial Behavior, Agency Costs and Ownership Structure", Journal of Financial Economics 3,305-360.

Hart,O.D. (1995), "Firms, contracts, and financial structure", Clarendon Press: Oxford, UN,.

Roll,R. (1986), “The Hubris Hypothesis of Corporate Takeovers", Journal of Business 59,197-216.

Xie,Z.; Kong,L.(2018), "Executives Overconfidence, Internal Control and Investment Efficiency-Empirical Evidence Based on Chinese A-share Listed Companies", Journal of Industrial Technological Economics 7,59-66.

Zhao,J.; Wang,J. (2020), "Regional differences and firms' innovation self-choice behavior: Insights from China", Sustainability 12,3866.

Wang,J.; Huang,G.;Gao,Y. (2016), "External Unfairness of Managerial Compensation and Inefficient Investment A Empirical Study Based on Social Comparison Theory", Collected Essays on Finance and Economics 2,63-71.

Higgins,R.C. (1981), "Performance degradation in a quadrature receiver for cw signals corrupted by multipath", 
The Journal of the Acoustical Society of America 69,728-731.

Tang,G.; You,Y.(2005), "Comparative analysis and case verification of sustainable growth model". Accounting Research 8,50-55.

Wang,L.; Han,J.;Gan,S. (2015), "Analysis, evaluation and reconstruction of foreign sustainable growth models", Statistics and Decision 5,78-80.

Yang,H.; Fu,B.;Zhao,Y.;Li,X. (2011), "Sustainable growth and cash dividends of state-owned Enterprises -- Based on the perspective of political relations and external governance environment", Journal of Chongqing University of Technology(Social Science) 1,43-54.

Yan,Z. (2016),"Literature review on inefficient investment and sustainable growth of small and medium sized science and technology enterprises", Accountant 2,13-14.

Yang,H.; Chen,G.;Yan,Z. (2011), "An empirical analysis of the impact of underinvestment on the sustainable growth of enterprises", Statistics and Decision 11,167-170.

Chen,C. (2018), "The challenge of sustainable growth", Enterprise Management 9,12-15.

Zhu,X.; Li,A.; Tang,Y. (2016), "Environmental Uncertainty, internal control and earnings management : Comparison between Accrual and real -Based Earnings Management", Finance and Accounting Monthly 32,15-20.

Richardson S. (2006), “Over-investment of Free Cash Flow”, Review of Accounting Studies 11,159-189.

Fang,H.; Jin,Y.(2013), "Corporate governance, internal control and inefficient investment: theoretical analysis and empirical evidence". Accounting Research 7,63-69.

Fazzari,S.M.; Hubbard,R.G.; Petersen,B.C. (1988), "Financing Constraints and Corporate Investment", Brookings Papers on Economic Activity 1,141-206.

Higgins,R.C.(2003), “Analysis For Financial Management”(sixth edition),Peking University press: Beijing, China,.

Van Horne J.C. (2000), "Financial management and policy”(eleventh edition). Dongbei University of Finance and Economics Press: Dalian,China.

Vogt S C. (1994), "The Cash Flow/ Investment Relationship: Evidence from U.S. Manufacturing Firms", Financial Management 23,3-20.

Wu,C.; Wu,S.;Cheng,J.;Wang,L. (2012), "The role of venture capital in the investment and financing behavior of listed companies :Evidence from China". Economic Research Journal 1, 105-119.

Lin,C., Su,D.(2008), "Industrial diversification, partial privatization and firm valuation: evidence from publicly listed firms in China", Journal of Corporate Finance 14, 405-417.

Petersen, M. (2009), "Estimating standard errors in finance panel data sets: comparing approaches", The Review of Financial Studies 22, 435-480.

Chen,Y.; Li,X.; Li,M. (2015), "Catering Cash Dividend Decision, Refinancing Needs and Corporate Investment - Policy Effectiveness of Semi-mandatory Cash Dividend under Investment Efficiency Perspective", Accounting Research 11,69-75.

Xiao,M. (2010), "Cash dividend, internal cash flow and investment efficiency", Journal of Financial Research 10,117-134.

Zhang,Y.; Chen,Q (2015), "An empirical research on the relationship between accounting culture and the growth of SMEs: based on the empirical data of the GEM", Accounting Research 3,20-25.

Alzahrani, M.; Lasfer, M. (2012), "Investor protection, taxation and dividends", Journal of Corporate Finance 6, $745-762$.

An,Z.(2012), "Taxation and capital structure: empirical evidence from a quasi-experiment in China”, Journal of Corporate Finance 18, 683-689. 